\title{
GAMBARAN PERAWATAN ANAK DIARE DI PUSKESMAS PROVINSI BALI
}

\author{
${ }^{1}$ Nyoman Ribek ${ }^{2}$, Ketut Labir ${ }^{2}$, Maria Dossantos ${ }^{3}$, Nengah Setiawati ${ }^{4}$, dan Ni \\ Nengah Suastini ${ }^{5}$ \\ 1,2,3,4,5 Politeknik Kesehatan Jurusan Keperawatan Denpasar \\ Email :nyomanribek0606@gmail.com, iketutlabir2016@gmail.com
}

\begin{abstract}
Description of Diarrhea Treatment in Children at the Health Center. The purpose of this study was to obtain a picture of the treatment of diarrhea performed in children in the Community Health Center. This study uses a qualitative research design with a case study approach. There were 8 participants in this study, namely 2 nurses who treated diarrhea children and 6 diarrhea children who were seeking care at the community health center. Participants were considered valid as informants because the 2 nurses already had experience in treating diarrhea while 6 diarrhea children were considered valid as informants at the time of participatory observation. Data from interviews, observations and documentation were analyzed according to miles and huberman including reduction, presentation and verification. It was concluded that to overcome the problem of readiness to improve fluid balance, hypovolemia and nutritional deficits in diarrhea patients given Paracetamol syrup $120 \mathrm{mg} / 5 \mathrm{ml}$, Neo Kaolana syrup $120 \mathrm{ml}$, zinc syrup and oralit. Paracetamol is given as a heat-lowering, Neo kaolana as a medicine for diarrhea, absorbs bacteria, toxins in the digestive tract and zinc also functions to treat diarrhea and oralit to relieve dehydration.
\end{abstract}

Keywords: Treatment, diarrhea, sick children

\begin{abstract}
Abstrak. Gambaran Perawatan Diare pada Anak di Puskesmas. Tujuan penelitian ini adalah untuk memperoleh gambaran tentang perawatan diare yang dilakukan pada anak di Puskesmas. Penelitian ini menggunakan rancangan penelitian kualitatif dengan pendekatan studi kasus. Partisipan penelitian ini ada 8 orang yaitu 2 orang perawat yang merawat anak diare dan 6 orang anak diare yang sedang mencari perawatan di Puskesmas . Partisipan dianggap valid sebagai informan karena 2 perawat tersebut sudah memiliki pengalaman dalam perawatan diare sedangkan 6 anak diare dianggap valid menjadi informan pada saat observasi partisipasi. Data hasil wawancara, observasi dan dokumentasi dianalisis menurut miles dan huberman meliputi reduksi, peyajian dan verifikasi. Disimpulkan bahwa untuk mengatasi masalah kesiapan peningkatan keseimbangan cairan, hipovolemia dan deficit nutrisi pada pasien diare diberikan Paracetamol syrup $120 \mathrm{mg} / 5 \mathrm{ml}$, Neo Kaolana sirup $120 \mathrm{ml}$, Zink sirup dan Oralit. Paracetamol diberikan sebagai penurun panas, Neo kaolana sebagai obat diare, menyerap bakteri,racun didalam saluran cerna dan Zink juga berfungsi untuk mengatasi diare serta oralit untuk meredakan dehidrasi.
\end{abstract}

Kata Kunci : Perawatan, diare, anak sakit 


\section{PENDAHULUAN}

Diare dapat diartikan sebagai bagian dari pengeluaran tiga atau lebih tinja encer atau cair per hari. Diare merupakan gejala infeksi di saluran pencernaan, yang dapat disebabkan oleh berbagai bakteri, virus dan parasite organisme. Infeksi menyebar melalui makanan atau air minuman yang terkontaminasi atau dari orang ke orang sebagai akibat kebersihan yang buruk 1) Kejadian diare disebabkan oleh beberapa faktor diantaranya keadaan lingkungan, gizi, dan perilaku masyarakat. Faktor lingkungan yang mempengaruhi diare adalah faktor air yang digunakan sehari-hari misalnya air PDAM atau sumur dan faktor perilaku yang mempengaruhi terjadinya diare yaitu praktek penanganan diare di keluarga baik yang dilakukan oleh ayah, ibu, maupun anggota keluarga yang lainnya seperti kebiasaan mencuci tangan yg baik dan benar serta menggunakan jamban yg layak untuk mencegah diare ${ }^{2)}$. Masalah diare menjadi persoalan serius bila tidak segera teratasi dapat mengakibatkan kamatian. Secara global, hampir 1,7 miliar kasus penyakit diare terjadi pada anak .Setiap tahun ada 1,6 juta kematian karena diare terjadi di seluruh dunia di 2010, dan akan terjadi serupa dengan angka-angka yang terjadi di tahun-tahun berikutnya ${ }^{3)}$

Berdasarkan kelompok umur penduduk, umur anak Balita merupakan kelompok umur paling tinggi menderita diare, Insiden diare di Indonesia adalah 6,7\% 4) Angka kejadian diare di provinsi Bali tahun 2017 sebanyak 22.291 rang, dari angka tersebut didapatkan sebanyak 3.034 orang dari Kabupaten karang
Asem dan 1.955 orang dari Kabuaten Bangli dan tertinggi untuk Kabupaten Bangli ada di Puskesmas Susut sebanyak 310 orang ${ }^{5}$ )

Diare adalah gangguan fungsi penyerapan dan sekresi dari saluran pencernaan, yang dipengaruhi oleh fungsi kolon dan dapat diidentifikasikan dari perubahan jumlah, konsistensi, frekuensi dan warna dari tinja ${ }^{6}$.

Berbagai masalah timbul pada anak yang mengalami diare, hasil penelitian yang diteliti oleh Rosari di kelurahan Lubuk Buaya Kecamatan KotoTengah Kota Padang ditemukan penderita anak diare sebagian besar mengalami defisit nutrisi yaitu penurunan nafsu makan $(81,1 \%)^{7)}$ Masalah utama yang paling umum terjadi karena diare adalah deficit nutrisi yang mengakibatkan terjadinya peningkatan penyakit infeksi karena asupan makanan yang menurun, malabsorpsi, dan katabolisme tubuh meningkat ${ }^{7)}$ Akibat dari pada deficit nutrisi akan terjadi kehilangan cairan dan elektrolit sebagai penyebab utama kematian diare ${ }^{8}$. Defisit nutrisi pada diare adalah asupan nutrisi yang tidak cukup untuk memenuhi kebutuhan metabolisme yang ditandai dengan berat badan menurun minimal $10 \%$ di bawah rentang ideal, cepat kenyang setelah makan, kram/nyeri abdomen, nafsu makan menurun dan bising usus hiperaktif. ${ }^{9)}$ Masalah diare yang lain yaitu kesiapan peningkatan keseimbangan cairan dan hipovolemia. Penelitian ini bertujuan untuk mengetahui gambaran perawatan diare pada anak di puskesmas provinsi Bali.

\section{METODE}


Penelitian ini menggunakan metode penelitian deskripsi kualitatif dengan pendekatan studi kasus. Penelitian ini dilakukan di Puskesmas Kabupaten karang Asem dan Puskesmas Bangli tahun 2019. Partisipannya dalam penelitian ini adalah perawat yang bekerja di puskesmas sebanyak 2 orang dan 6 orang pasien diare yang terdiri dari 2 pasien resiko hipovolemia dan 2 pasien deficit nutrisi serta 2 orang pasien Kesiapan Peningkatan Keseimbangan Cairan. Partisipan dipilih dengan metode purposive sampling untuk mencapai saturasi data. Cara mengumpulkan data dengan wawancara mendalam dan observasi partisipasi serta dokumentasi. Sebelum melakukan penelitian peneliti mengajukan kelaikan etik di instansi setempat dan dinyatakan laik etik.

\section{HASIL DAN PEMBAHASAN}

Data yang didapatkan pada penelitian ini setelah dilakukan reduksi data didapatkan empat data yaitu data pengkajian, data rencana tindakan , data pelaksanaan dan data evaluasi. Data tersebut disajikan dalam tema, sub tema. Tema dengan bold, sub tema dengan italic. Pemaparan keempat data diperoleh dari hasil wawancara 2 perawat, 6 dokumentasi pasien dan observasi 6 pasien.

Data pengkajian. Dalam pengkajian didapatkan data sebagai berikut: " Data pasien pertama dari desa Tiga Susut Bangli dengan kasus diare didapatkan data anak umur 3 tahun, perempuan dari Desa Tiga Susut Bangli mengalami diare akut dehidrasi ringan sejak satu hari yang lalu dengan keluhan buang air besar encer disertai dengan perut mules dan melilit dengan frekuensi buang air besar $4 x$ per hari serta lemas dan muntah $2 x$ sehari, napsu makan berkurang. Orang tua pasien mengatakan anaknya tidak diberikan obat, hanya diberi makan bubur dan teh hangat sejak diare, feces cair warna kuning turgor kulit kurang elastis, nadi 90x/menit, respirasi rate $=30 \mathrm{x}$ /menit, suhu $=36,5^{\circ} \mathrm{C}$. Disimpulkan pasien diare itu diagnose keperawatannya Resiko Hipovolemia . Data pasien kedua dari desa Tiga Susut Bangli, dengan kasus diare didapatkan data pasien umur 2 tahun, laki-laki, buang air besar encer $4 x$ sehari sejak 3 hari, muntah 2 - 4 kali sehari, lemas dan tidak mau makan. Ibu pasien mengatakan perawatan dirumah hanya dikompres dan anaknya tidak mau makan dan minumnya sedikit, mukosa bibir kering, turgor kulit kurang elastis, nadi 100 kali per menit, respirasi rate $=35$ kali per menit, suhu $=36^{\circ} \mathrm{C}$ disimpulkan diagnose keperawatannya Resiko Hipovolemia . Data pasien ketiga diare didapatkan pasien umur 4 tahun, laki, sejak 1 hari yang lalu frekuensi buang air besar 6 kali sehari dengan konsistensi feses cair, nyeri abdomen, mual dan muntah, nafsu makan menurun, menolak untuk makan, makan hanya habis 1/4 porsi nasi lembek, berat badan sebelum sakit $12 \mathrm{~kg}$, selama sakit 10 $\mathrm{kg}$, bising usus hiperaktif, membran mukosa pucat dan suhu $38,2{ }^{\circ} \mathrm{C}$. Disimpulkan diagnosa kepera watanya defisit nutrisi. Data pasien keempat diare didapatkan pasien umur 6 tahun, laki, sejak 1 hari yang lalu, frekuensi buang air besar 5 kali sehari dengan konsistensi feses cair, nyeri abdomen, mual dan muntah, nafsu makan menurun, makan habis 3 sendok makan bubur berat badan sebelum sakit $23 \mathrm{~kg}$, selama sakit $21,5 \mathrm{~kg}$, bising usus 
hiperaktif, membran mukosa pucat, suhu $36,6{ }^{\circ} \mathrm{C}$, Disimpulkan diagnosa keperawatan defisit nutrisi. Data pasien kelima diare didapatkan anak umur 3 tahun, perempuan, sejak 1 hari yang lalu buang air besar sebanyak 6 kali dengan feses cair warna kuning, muntah, lemas, panas dan makan minum sedikit. Kesadaran compos mentis. suhu : $38,7{ }^{\circ} \mathrm{C}$, nadi 84 kali per menit, respirasi rate 24 kali per menit, membran mukosa lembab, tidak ada dehidrasi. Disimpulkan diagnosa keperawatan yang timbul Kesiapan Peningkatan Keseimbangan Cairan berhubungan dengan syndrome iritasi usus. Data pasien keenam diare didapatkan anak umur 2 tahun, perempuan, sejak 1 hari yang lalu buang air besar sebanyak 5 kali dengan feses cair warna kuning, muntah, lemas makan dan minum sedikit, kesadaran compos mentis, suhu $37^{\circ} \mathrm{C}$, nadi 80 kali per menit, respirasi rate 22 kali per menit, membran mukosa lembab, tidak ada dehidrasi, disimpulkan diagnosa keperawatan kesiapan peningkatan keseimbangan cairan"

\section{Data Rencana dan}

Implementasi. Data rencana dan Implementasi keperawatan didapatkan data sebagai berikut:

"Pada pasien pertama rencana tindakannya mengecek tanda-tanda vital, memberikan larutan garamgula, memberikan edukasi cara mencuci tangan yang benar, memberitahu orang tua agar anak diistirahatkan ,dan memberi edukasi pemberian obat yang diberikan meliputi Paracetamol 3x1 cth, Zink syrup 1x1, dan oralit. Pada pasien kedua rencana tindakannya mengecek tanda-tanda vital, memberikan larutan garam-gula, memberikan edukasi cara mencuci tangan yang benar, memberitahu orang tua agar anak diistirahatkan, dan memberi edukasi pemberian obat yang diberikan meliputi Paracetamol 3xl cth, Zink syrup 1x1, dan oralit . Pada pasien ketiga rencana tindakannya mengkaji keadaan umum dan mengecek tanda vital, timbang berat badan, memberikan makanan sedikit tapi sering dan makanan tambahan, memberikan penjelasan kepada keluarga tentang diet nutrisi yang berkaitan dengan penyakit yang diderita pasien, kolaborasi dalam pemberian obat, Pada pasien keempat demam rencana tindakannya mengkaji Keadaan umum, mengukur tanda vital, timbang berat badan, berikan makanan sedikit tapi sering dan makanan tambahan, memberikan penjelasan kepada keluarga tentang diet nutrisi yang berkaitan dengan penyakit yang diderita pasien, Kolaborasi dalam pemberian obat. Pada pasien kelima rencana tindakannya mengkaji keadaan umum, mengukur tanda vital timbang berat badan, memberikan makanan sedikit tapi sering dan makanan tambahan, memberikan penjelasan kepada keluarga tentang diet nutrisi yang berkaitan dengan penyakit yang diderita pasien. Dann pemberian obat Paracetamol syrup $120 \mathrm{mg} / 5 \mathrm{ml}$, Neo Kaolana syrup 120 $\mathrm{ml}$ dan oralit sachet Pada pasien keenam rencana tindakannya mengobsevasi tanda vital, timbang popok, anjurkan banyak minum, amati tanda dehidrasi, kolaborasi dalam pemberian obat Paracetamol syrup $120 \mathrm{mg} / 5 \mathrm{ml}$, Neo Kaolana syrup $120 \mathrm{ml}$ dan oralit . 
Data Pelaksanan Tindakan. Data pelaksanaan tindakan didapatkan data sebagai berikut:

"Pada pasien pertama tindakan perawatannya mengukur tanda vital didapatkan tensi meter 105/ 65, suhu tubuh 37, tekanan nadi 60 kali pemenit, memberikan oralit sachet 3 bungkus dengan edukasi oralit diminum setiap mencret dan 10 menit setelah muntah serta oralit diberikan sampai buang air besarnya berhenti, edukasi cara memberikan oralit sachet adalah mencuci tangan, menyiapkan air hangat satu gelas atau 200 cc buka kemasan oralit, tuangkan bubuk oralit ukuran 200 cc kedalam air, aduk merata hingga larut lalu diminum. Kolaborasi pemberian obat zinc sirup selama 10 hari kendati buang air besar sudah berhenti. Pada pasien kedua pelaksanaan perawatan didapatkan tekanan darah 100/65, suhu $36,8^{\circ} \mathrm{C}$ , memberikan larutan garam-gula, memberikan cara mencuci tangan yang benar, memberitahu orang tua agar anak diistirahatkan. Pada pasien ketiga pelaksanaan perawatannya didapatkan tekanan darah 105/65 , suhu $36,6{ }^{\circ} \mathrm{C}$, memberikan larutan garam-gula, berat badan $10 \mathrm{~kg}$ memberikan penjelasan kepada keluarga tentang diet nutrisi yang berkaitan dengan penyakit yang diderita, kolaborasi untuk pemberian obat : Paracetamol syrup $120 \mathrm{mg} / 5$ eo Kaolana syrup $120 \mathrm{ml}$ dan Oralit .Pada pasien keempat pelaksanaan perawatannya didapatkan tekanan darah 105/60, suhu $36,8{ }^{\circ} \mathrm{C}$, memberikan larutan garam-gula, menimbang berat badan hasilnya $21,5 \mathrm{~kg}$, memberikan penjelasan kepada keluarga tentang diet nutrisi. Pada pasien kelima pelaksanaan perawatan didapatkan tekanan darah 100/65, suhu $36,8^{\circ} \mathrm{C}$ , memberikan larutan garam-gula, menganjurkan keluarga memberikan minum sedikit tapi sering. Kolaborasi dalam pemberian anti diare, edukasi tentang PHBS yang dapat memicu terjadinya diare, penanganan diare, pentingnya cairan pada pasien diare, tandatanda dehidrasi. Pada pasien keenam diare dengan kesiapan Peningkatan keseimbangan cairan pelaksanaan perawatan mengukur tanda vital, memeberikan minum sedikit tapi sering. memberikan edukasi tentang PHBS yang dapat memicu terjadinya diare, edukasi pentingnya cairan pada pasien diare,

Data Evaluasi keperawatan . Data evaluasi keperawatan didapatkan data sebagai berikut:

" Pada pasien pertama evaluasi perawatanya yaitu pada hari ke tiga badan masih lemas, mata tidak cekung, turgor kulit baik suhu 36,5oC, RR :30x/mt, Data pasien kedua evaluasi perawatnnya yaitu pada hari ke tiga badan sudah tidak lemas. buang air besar satu kali padat Data pasien ketiga evaluasi perawatannya pada hari ke tiga panas badan sudah tidak ada, suhu 36,5 oC, nadi: $80 x / m t$. Data evaluasi pasien ke empat dihari ke tiga panas badan sudah tidak ada, suhu 36,5 oC, nadi :80x/mt Data evaluasi pasien ke lima dihari ke tiga keluarg mengatakan mual muntah anak sudah berkurang frekwensi buang air besar 1 kali dan feses sudah tidak cair sekali, tidak ada nyeri perut, bising usus normal. Data evaluasi pasien ke enam dihari ke tiga keluarga mengatakan mual muntah sudah berkurang frekwensi 
satu kali dan feses sudah tidak cair sekali.

Pernyataan dan dokumen data tersebut menunjukkan bahwa dalam melaksanakan perawatan pada pasien diare melalui proses yaitu pengkajian, perencanaan, pelaksanaan dan evaluasi, tetapi didalam pengkajian ada diagnose keperwatan sehingga jika diuraikan proses perawatan ada 5 langkah yaitu pengkajian, diagnosis, perencanaan, pelaksanaan dan evaluasi. Pengkajian yang didapat dari keenam pasien didapatkan data buang air besar dengan feces encer, tidak berlendir dan frekwensinya $4 \mathrm{x}$ sehari, $4 \mathrm{x}$ sehari, $6 \mathrm{x}$ sehari, $5 \mathrm{x}$ sehari dan $6 \mathrm{x}$ sehari disertai muntah sehingga disimpulkan diare yaitu peningkatan frekwensi buang air besar lebih dari $3 \mathrm{x}$ sehari dengan konsistensi tinja cair 11) Pada keenam pasien feces yang dikeluarkan lunak dan tidak berbentuk ${ }^{10)}$ Diagnosa keperawatan yang muncul dari keenam pasien diare tersebut yaitu deficit nutrisi cairan, Hipovolemia dan kesiapan peningkatan keseimbangan cairan. Kesiapan Peningkatan Volume Cairan adalah Pola ekulibrium antara volume cairan dan komposisi kimia cairan tubuh yang cukup untuk memenuhi kebutuhan fisik dan dapat ditingkatkan,sedangkan deficit nutrisi asupan nutrisi yang tidak cukup untuk memenuhi kebutuhan metabolism, serta Hipovolemia adalah penurunan volume cairan intra vascular, interstisial dan atau intraseluler ${ }^{9)}$. Pelaksanaan tindakan keperawatan keenam pasien diare sedikit berbeda dimana pada pasien diare yang dilaksanakan pada pasien pertama dan kedua dari Bangli menggunakan Zink syrup sedangkan pasien 3,4,5 dan 6 menggunakan Kaolana syrup $120 \mathrm{ml}$ walau kedua obat tersebut berbeda tetapi memiliki indikasi yang sama yaitu sebagai suplemen meningkatkan daya tahan tubuh dan penyerapan bakteri pasien diare. ${ }^{12)}$ Obat-obatan yang juga disertainya adalah parasetamol syrup (asetaminofen) karena Parasetamol cepat bereaksi dalam menurunkan panas kendatipun pasien dalam penelitian ini tidak dalam keadaan panas ${ }^{13)}$. Setelah hari ketiga perawatan hasilnya buang air besar hanya sekali, tidak muntah dan feces kental, inilah disebut evaluasi perawatan yaitu membandingkan status keadaan kesehatan pasien dengan tujuan atau kriteria hasil yang telah ditetapkan 14) Dalam tindakan perawatan itu juga ditekankan pentingnya edukasi kesehatan tentang pentingnya mencucu tangan. Hal ini penting karena edukasi kesehatan yang sering disebut dengan pendidikan kesehata adalah suatu upaya atau kegiatan untuk menciptakan perilaku masyarakat yang kondusif untuk kesehatan artinya, pendidikan kesehatan berupaya agar masyarakat menyadari atau mengetahui bagaimana cara memelihara kesehatan mereka, bagaimana menghindari atau mencegah hal - hal yang merugikan kesehatan mereka dan kesehatan orang lain, kemana seharusnya mencari pengobatan jika sakit, dan sebagainya ${ }^{15)}$. Dengan demikian maka mencuci tangan merupakan erilaku utama dalam mencegah terjadinya diare.

\section{SIMPULAN}

Berdasarkan hasil pembahasan disimpulkan bahwa Diare adalah gangguan saluran pencernaan yang 
mengakibatkan terjadinya buang air besar dengan feces cair lebih dari 3 kali sehari. Dalam melaksanakan perawatan anak Diare dengn masalah Defisit Nutrisi, Hipo volemia dan Kesiapan peningkatan kebutuhan cairan dengan tahap proses perawatan yaitu pengkajian, dignosa keperawatan, perencanaan, pelaksanaan dan evaluasi. Pada tahap pengkajian pasien hipovolemia , dan defisit nutrisi dengan diare ditemukan frekwensi buang air besar lebih dari 3 kali sehari dan encer maka perawatannya diberikan oralit dan Neokaolana sirup atau Zink sirup. Oralit berfungsi mencegah terjadinya dehidrasi, sedangkan Neokalana atau Zink berfungsi untuk meningkatkan daya tahan tubuh dan penyerapan bakteri. Dalam mengantisipasi tingginya suhu panas badan naik diberikanlah paracetamol. dan anjuran minum

\section{DAFTAR PUSTAKA}

1. WHO G. WHO recommendations on the management of diarrhoea and pneumonia in HIV-infected infants and children. 2010;(Imci).

2.Fatmawati;Arbianingsih;Musdalifa h. Faktor Yang Mempengaruhi Kejadian Diare Anak Usia 3-6 Tahun di TK Raudhatul Athfal Alauddin Makassar. 2015;1:2132.

3. WHO. Diarrhoeal disease WHO 2017.

4. Riset Kesehatan Dasar; RISKESDAS. In: Depkes RI. Jakarta: Badan Penelitian dan Pengembangan Kementerian Kesehatan RI.; 2013:34-36.

5. Dinkes. profil kesehatan kabupaten karangasem. 2017.

6. Ridha HN. Buku Ajar Keperawatan Anak. 1st ed. (Riyadi sujono, ed.). Yogyakarta: Pustaka Pelajar; 2014. yang cukup, sehingga dalam 3 hari perawatan anak buang air besar hanya sekali, kental, mau minum yang berarti tidak terjadi diare .

\section{UCAPAN TERIMA KASIH.}

Terima kasih disampaikan kepada team manajemen Puskesmas Selat Karang Asem, dan Puskesmas Susut 1 Bangli yang telah menfasilitsi dan menjadikan tempat penelitian ini sehingga penelitian bisa selesai.

\section{ETIKA PENELITIAN}

Etika penelitian ini diperoleh dari Politeknik Kesehatan Denpasar dan Sumber Dana Penelitian ini bersumber dari dana mandiri

\section{SUMBER DANA}

Dana Penelitian ini bersumber dari dana mandiri

7. Rosari A, Rini EA, Masrul. Hubungan Diare dengan Status Gizi Balita di Kelurahan Lubuk Buaya Kecamatan Koto Tangah Kota Padang. J Kesehat Andalas. 2013;2(3):111-115.

8. Sodikin. Asuhan Keperawatan Anak; Gangguan Sistem Gastrointestinal Dan Hepatobilier. Salemba Me. Jakarta Timur; 2011.

9. Tim Pokja SDKI DPP PPNI. Standar Diagnosa Keperawatan Indonsia. Jakarta: PPNI Pusat; 2017.

10. PPNI. Standar Diagnosis Keperawatan Indonesia.; 2017.

11. Koes I. Epidemologi Penyakit Menular dan Tidak Menular Panduan Klinis. 2015.

12. Olivia Chyntia Devi. Informasi Obat Baru. Jakarta: Gramedia; 2018. 
Nyoman Ribek, Ketut Labir, Maria Dossantos, Nengah Setiawati , dan Ni

Nengah Suastini. Juni 2020.13 (1):21-28

13. Graneto J. Pediatric Fever. Chucago university; 2010.

14. Tarwoto, Wartonah. Kebutuhan Dasar Manusia Dan Proses Keperawatan. 5th ed. Jakarta: Salemba Medika; 2015.
15. Notoatmodjo S. Ilmu Kesehatan Masyarakat; Prinsip-Prinsip Dasar. Jakarta: Rineka Cipta; 2007. 